\title{
Factors Contributing to Brand Loyalty towards Malaysia Higher Educational Institutions
}

\author{
*Mona Fairuz Ramli, Rahim Othman, Salniza Md. Salleh \\ Universiti Utara Malaysia, Malaysia \\ *monafairuz78@gmail.com
}

\begin{abstract}
This study aimed at filling the gap in the current marketing literature on the driver of brand loyalty towards public higher education institutions in Malaysia. The drivers of brand loyalty studied include university image and perceived teaching and learning quality. Toward meeting the objective, a selfadministrated questionnaire was employed. Smart PLS was used to analyze data from 150 international students of Universiti Utara Malaysia. The result revealed that university image and perceived teaching and learning quality were significantly linked to each other and significantly affected brand loyalty. Proximity this finding will help policy maker to design or develop new marketing strategy in higher education institution which is compatible with student perception as well as to increase the number of international student enrollment.
\end{abstract}

Keywords: University image, perceived teaching and learning quality, brand loyalty

\section{Introduction}

Branding has become a corporate strategy for many higher learning institutions (HEIs) to enable them to compete locally and internationally. With a powerful branding and unique corporate identities, HEIs can differentiate themselves among their competitors (So, Parsons, \& Yap, 2013; Watkins \& Gonzenbach, 2013). More importantly, a strong brand can enhance market awareness among potential customers as well as market share (Bennett \& Ali-Choudhury, 2009). Hence, a strong brand should be recognizable and meaningful to consumers (Watkins \& Gonzenbach, 2013) to ensure student retention and student loyalty (Helgesen \& Nesset, 2007a; Hennig-Thurau et al., 2001; Vander Schee, 2010). Hennig-Thurau et al. (2001) argued that student loyalty is synonymous with student retention. Brand loyalty is becoming a major goal of many higher education institutions and not surprisingly many are using student loyalty to measure performance. In fact, successful universities are those that can develop student loyalty. For these universities, investing in student retention is better than investing in new student enrollment because student retention can enhance the survival of the institutions (Williams Jr, Osei, \& Omar, 2012) .

Understanding the main predictor of student loyalty will assist marketing managers and policy makers in HEIs to outline their strategies in order gain competitive advantage particularly brand creation (Fernandes, Ross, \& Meraj, 2013). Service marketing literatures in education identify university image and perceived quality as the relevant antecedents of loyalty (Helgesen \& Nesset, 2007a; Vander Schee, 2010). However, most of the preliminary studies in brand loyalty have only carried out in a small number of areas higher education institutions(HEIs) (Gounaris \& Stathakopoulos, 2004; Bianchi, Drennan, \& Proud, 2014). Therefore, this study attempted to investigate the drivers of brand loyalty in HEIs as suggested by a number of scholars (Mupemhi, 2013; Obermeit, 2012). A higher education institution with a strong brand name conveys a positive image and reputation and is capable of delivering high quality education. It has been found that a strong brand name is identifiable, enduring, and meaningful to consumers (Louis \& Lombart, 2010). Further, Sean, Hyun, and Kim (2011) and Tran, Nguyen, Melewar, and Bodoh (2015) proposed that image could be derived from consumer perception, experience, and feeling towards the object (product, services, firms and brand). Accordingly, this study extended the existing work by researching international students' impressions, belief, feeling, and knowledge to identify how a university's image affects their current places of study.

Existing studies showed that a university image is the most essential factor that influence potential students to choose public universities as their study destination (Khairani \& Razak, 2013; Hoyt \& Brown, 2003). 
However, according to Tas and Ergin (2012), literatures in the topic of university image are still lacking even though many researchers in marketing have recognized the critical roles of image and perceived quality in consumer buying behavior (Andreassen \& Lindestad, 1998; Milfelner, Snoj, \& Pisnik Korda, 2011; Sean Hyun \& Kim, 2011). These two constructs have also been shown as important in developing and maintaining customer loyalty (Helgesen \& Nesset, 2007b; Lin \& He, 2014; Wu, 2013). Also, literatures reveal a few empirical evidence to support the study of university image by (Jin, Lee, \& Lee, 2013; Sean Hyun \& Kim, 2011). Based on the gaps identified in the literatures, this study aimed at identifying international students' perception of the image and the quality of teaching and learning quality of the university, and how their perception affects their loyalty towards the university. Toward this objective, we organized this paper into four sections. First, a review on university image, perceived teaching and learning quality and brand loyalty is discussed. Then the method employed to meet the research objective is outlined. Next, the result of the study is offered. Then, a discussion of the result as well as implications for higher educational institutions, particularly marketing managers and policy makers, is presented.

\section{Literature Review and Hypotheses Development}

Brand loyalty: According to Oliver (1999), brand loyalty is a customer commitment to consume and patronize a favorite product and services consistently in future. Loyal customer has intention to share positive experiences with other people regarding the same brand name. Sirdeshmukh, Singh, and Sabol (2002) also contended that expressed loyalty is an intention to act a diverse set of behavior such as positive word of mouth, repeat of higher purchase, and pay a premium price to a certain brand or object. Meanwhile, Jacoby and Kyner (1973) related brand loyalty to a psychological construct, which is a result of both attitude and behavior. This is consistent with other definitions that have been proposed to measure loyalty. Essentially, brand loyalty has attitudinal and behavioral components (Baloglu, 2002; Chaudhuri \& Holbrook, 2001). Although there are many antecedents that affect loyalty, the objective this current study was to investigate the potential antecedents of customer loyalty towards non-profit organization (university), (Ashby, Richardson, \& Woodley, 2011; Clemes, Cohen, \& Wang, 2013; Richardson, Slater, \& Wilson, 2007a, 2007b).

University image: Kotler and Fox (1995) stated that university image can be defined in many ways. Some researchers defined university image as a set of beliefs and impression about a place, destination or organization (Chun, 2005; Mercedes Marzo-Navarro, Pedraja-Iglesias, \& Rivera-Torres, 2005; OlmedoCifuentes, Martinez-Leon, \& Davies, 2014). Literatures show that image can be developed on different things such as product, brand, and organization (Cretu \& Brodie, 2007; Lemmink, Schuijf, \& Streukens, 2003; Nguyen \& LeBlanc, 2001; Tran, Nguyen, Melewar, \& Bodoh, 2015). Literatures also indicate that customers who possess a good image of a product and services tend to have favorable attitude towards product or services brand as well as towards the brand's product quality (Kandampully, Juwaheer, \& Hu, 2011; Sean Hyun \& Kim, 2011). Consistently, Andreassen and Lindestad (1998) and Dla, Arslanagi, and Kadi (2013) believed that image influences customer perception on quality and value of the product or services. Therefore the following hypothesis was proposed.

\section{H1: There is a significant relationship between university image and perceived quality}

Perceived quality and brand loyalty: This study defined perceived quality as the overall judgment and the generally excellent or superior evaluation by a customer on the quality services (Zeithaml, Berry, \& Parasuraman, 1988). Also, Zeithmal, Parasuraman, and Berry (1990) pointed out that balancing between perception and customer expectation in delivering service quality influences customer satisfaction towards service providers. Later, Zeithaml, Berry, and Parasuraman (1996) defined perceived service quality as a differentiation or comparison of customer expectation with their perceptions of product or services performance. In recent years, researchers have investigated a variety of approaches to measure perceived quality. However, the essential problem in the implementation of such approaches lies in the nature of service quality construct in which its representation is extremely difficult to define and measured (Abdullah \& Zamhari, 2013; Ahmad, 2014; Anadol, 2013). In the context of services industry SERVQUAL could measure empirically, however it is still being debated for a number of reasons (Sultan \& Wong, 2010; Nadiri et al., 2009; Lother Kreck, 1997). For example, Kreck (1997) questioned the dimensionality and items for measure of SERVQUAL in their studies. On the other hand, SERVPERF dimension only focuses on customer perception on service quality and is difficult to apply in other industries like higher education institutions (Abdullah \& of 
studenZamhari, 2013). Abdullah (2006) developed Higher Education Performance (HEdPERF), comprising 41 items to examine perceived quality in higher education institutions. Thus, this instrument is limited in its scope in which student expectation and services performance paradigm in HEI's (Aslam et al., 2012; Abdul Manaf, Ahmad, \& Ahmad, 2013). While literatures show that studies on perceived quality and satisfaction are already matured (Ahmad, 2014; Khan, Ahmed, \& Nawaz, 2011), perceived teaching and learning quality is posited to be related to creating brand loyalty in higher education (Ashby et al., 2011; Vander Schee, 2011). It is somehow dissimilar the predictors of brand loyalty. In fact, previous studies on perceived quality and brand loyalty have shown that these constructs are crucial for measuring student loyalty in context student as a consumer in HEIs (de Macedo Bergamo et al., 2012; Hennig-Thurau et al., 2001). Therefore, this study attempted to minimize the gap of perceived quality in higher education institutions context. Consequently, the following hypothesis was formulated.

H2: There is a significant relationship between perceived quality and brand loyalty

\section{Methodology}

Data collection and sample profile: Data were collected in September 2014 and ended by mid October 2012 randomly selected of 150 undergraduate and postgraduate international students of Universiti Utara Malaysia (UUM). Toward meeting the objective, a self-administrated questionnaire was employed to collect data from international students. The intercept survey method was used to collect the data from three different colleges. Of 150 questionnaires distributed, 101 (67.3 percent) were valid for analysis. The majority of the respondents were male $(61.4 \%)$ compare female student only (38.6\%). Sample size is adequate for reliability and validity interpretation according to (Nunnally \& Bernstein, 1978).

Measures: This study adapted the scales from established measures of university image, perceived teaching and learning quality, and brand loyalty. The measure of university image was adapted from Lymar and Mohajerani (2013), which was modified and adapted from Bennett and Ali-Choudhury (2009b). The final measure had three dimensions with 21 items: Covenant (4 items), quiddity (15 items), and symbolic and external representation ( 3 items). The measure of perceived teaching and learning quality (PTQ) was adapted from Richardson et al. (2007a). The PTQ scale includes 35 items, representing nine dimensions: The teaching course was measured by five items, organization and management, personal development, career and development were measured by four items each, and feedback on submitted work, assessment on the courses, workload, support and advice were measured by three 3 items each. Finally brand loyalty was measured by 15 items adapted from Sui and Baloglu (2003) and Hennig-Thurau, Langer, and Hansen (2001). The instruments used a seven-point Likert scale, ranging from $1=$ strongly disagree to $7=$ strongly agree.

\section{Data Analysis and Results}

Data analysis method: Structural Equation Modeling (SEM) with Smart PLS 2.0 M3 (Ringle, Wende, \& Will, 2005), was used to examine the measurement model and structural model (hypothesis). This approach was selected because fewer demand in terms of number of sample size utilized, not required normal data distribution and also can be applied to complex structural equations models with large numbers of constructs compare with employed of CBSEM (covariance-based structural equation model technique) (Chin, Marcolin, \& Newsted, 2003). The following section discusses the examination of the measurement model and structural model using SmartPLS 2.0. Prior to evaluating the measurement model, preliminary data were made to ensure the data can parsimoniously explain the model and clean for further analysis.

Measurement model: Table 1 illustrates the findings of the analysis including the Cronbach's alpha of each variable such as university image $(\alpha=0.906)$, perceived quality $(\alpha=0.956)$, and brand loyalty $(\alpha=0.792)$. As shown, the alpha values exceeded the recommended threshold of 0.7 (Nunnally \& Bernstein, 1978). Further, the composite reliability (CR) ranged between 0.885 and 0.966 , and the average variance extracted (AVE) ranged between 0.505 and 0.654 . The CR values exceeded the recommended threshold of $C R \geq 0.7$, while the AVE values were more than the cut-off point of 0.5 ( Hair, Babin, \& Anderson, 2010). With reference to the results, the convergent validity of the measures was established ( Hair et al., 2010). 
Table 1: Convergent validity

\begin{tabular}{llllllll}
\hline Construct & $\mathbf{1}$ & $\mathbf{2}$ & $\mathbf{3}$ & No of items & Loadings & AVE & CR \\
\hline 1. Brand loyalty & 1 & & & 15 & $0.640-0.902$ & 0.654 & 0.966 \\
2. Perceived quality & 0.721 & 1 & & 35 & $0.628-0.776$ & 0.505 & 0.957 \\
3. University image & 0.512 & 0.719 & 1 & 21 & $0.656-0.794$ & 0.525 & 0.885 \\
\hline
\end{tabular}

Table 1 also shows the results of the discriminant validity assessment by investigative its average extracted AVE value. Convergent validity is acceptable when constructs have average variance extracted (AVE) value of at least more than cut off 0.5 . Moreover the result also indicate the value of the constructs' correlations and the square roots of AVE was less than 0.85 , it representing that there was no multicollinearity in the data set. This illustrate that the discriminant validity of the construct was confirmed (Fornell \& Larcker, 1981).

Structural model and hypothesis testing: The SmartPLS analysis was used to test the hypothesized relationships between the constructs in the proposed model. In order to test the hypothesis path, the SmartPLS bootstrapping was employed. The function of bootstrapping is used to generate the $t$-statistics values. While in this study SmartPLS bootstrapping use to generate 500 samples from 101 cases to obtain t- statistic values. In assessing the PLS model, the squared multiple correlations $\left(\mathrm{R}^{2}\right)$ of each endogenous latent variable were initially tested and significantly evaluated for the structural path in the measurement model (SmartPLS Algorithm). Table 3 shows the summarized results of path coefficient and $t$-values. The path analysis showed that university image had a significant effect on perceived teaching and learning quality $(\beta=0.719, t=16.383)$. It explained approximately $51.7 \%$ of perceived teaching and learning quality $\left(\mathrm{R}^{2}=0.517\right)$. Perceived quality also had a significant effect on brand loyalty construct $(\beta=0.721, t=12.302)$, and it explained approximately $52.0 \%$ of brand loyalty $\left(\mathrm{R}^{2}=0.520\right)$. While the values of $\mathrm{R}^{2}$ was greater than 0.26 (substantial) that was suggested by (Chin, 1998), it is high enough for the model to achieve a minimum level of explanatory power (Hair, Sarstedt, Ringle, \& Mena, 2012; Urbach \& Ahlemann, 2010).

Table 2: Result of the structural model

\begin{tabular}{lllllll}
\hline Hypothesis & Relationship & $\begin{array}{l}\text { Standard } \\
\text { beta }\end{array}$ & $\begin{array}{l}\text { Standard } \\
\text { Error }\end{array}$ & t-value & $\mathbf{R}^{2}$ & Decision \\
\hline $\mathrm{H} 1$ & $\begin{array}{l}\text { University Image } \rightarrow \\
\text { Perceived Quality }\end{array}$ & 0.719 & 0.048 & $14.872^{* *}$ & 0.517 & Supported \\
$\mathrm{H} 2$ & $\begin{array}{l}\text { Perceived Quality } \\
\text { Brand Loyalty }\end{array}$ & 0.721 & 0.056 & $12.900^{* *}$ & 0.520 & Supported \\
& & & & & &
\end{tabular}

\section{Discussion and Implication}

Our results showed that the international student's perception towards HEIs was affected by information gathered from marketing communication of the university itself (Hosseini \& Nahad, 2012). The favorable perception the students had might be explained by their academic performance and positive experience as students of the institution. The finding demonstrated that university image had a significant impact on perceived teaching and learning quality. This suggests that image involves the perception that is related to past experience and knowledge as an important predictor of teaching quality. In this manner, the result is consistent with previous studies (Aydin \& Ozer, 2005; Milfelner et al., 2011; Sean Hyun \& Kim, 2011). Our finding suggests that students are concerned with the teaching quality at the university, for instance, with the way the instructors explain the subject to make it interesting. Also, the assessment and feedback from the instructors is important to make them better understand the subject. In addition, the students expect to get support in their studies from their instructors for personal and career development.

Our finding further showed that perceived quality was a key antecedent of brand loyalty. The result is consistent with previous studies (Alves \& Raposo, 2010; Liat, Mansori, \& Huei, 2014; Perin, Sampaio, Simoes, \& de Polvora, 2012). We also demonstrated that university image and perceived teaching and learning quality significantly predicted brand loyalty. Based on our result, a positive perception on teaching and learning 
quality will impact the word-of-mouth marketing. In this context, our finding is similar to Çetin (2011) and Rubeena Cetin (2004), who asserted that a positive image of a university will facilitate the university in selecting good international students

Limitation and future research: This study makes several contributions to the marketing literature, especially to HEIs in Malaysia. However, despite these contributions, the findings must be viewed in light of the following limitations. Firstly, the sample was only taken from one public university and future research could expand the sample by including all public universities in order to reach a meaningful conclusion regarding perceived teaching and learning quality and brand loyalty path. Secondly, this study used nine dimensions of perceived quality (teaching course, organization and management, personal development, career and development, feedback on submitted work, assessment of the courses, workload, support and advice) to measure perceived quality and two dimensions to measure brand loyalty (attitudinal and behavioral). However this study did not discuss other issues that might be influencing the perception on brand image. For an example, Tran et al. (2015) argued that external communication, positive feeling, and environment are able to create a more consistent image. Therefore, future studies are recommended to investigate the interaction of such dimension to form brand image. Also, this study was cross-sectional in nature. Perhaps, a longitudinal study can be conducted to derive more enriched findings.

\section{References}

Abdul Manaf, N. H., Ahmad, K. \& Ahmad, S. (2013). critical factors of service quality in a graduate school of Malaysia. International Journal of Quality in Graduate School of Malaysia, 5(4), 415-431.

Abdullah, F. (2006). The development of HEdPERF: a new measuring instrument of service quality for the higher education sector. International Journal of Consumer Studies, 30, 569-581. doi:10.1111/j.14706431.2005.00480.x

Abdullah, F. \& Zamhari, U. A. (2013). Managing Critical Factors Affecting Service Quality for the Public Sector. In Proceedings of 23rd International Business Research Conference (pp. 1-17). Marriott Hotel, Melbourne, Australia.

Ahmad, S. Z. (2014). Evaluating student satisfaction of quality at international branch campuses. Assessment \& Evaluation in Higher Education, (August), 37-41. doi:10.1080/02602938.2014.925082

Alves, H. \& Raposo, M. (2010). The influence of university image on student behaviour. International Journal of Educational Management, 24(1), 73-85. doi:10.1108/09513541011013060

Anadol, G. Y. (2013). Winning in the Market Place by Defining Higher Education Quality Dimensions : A UAE Example. International Review of Business Research Paper, 9(6), 55-67.

Andreassen, T. W. \& Lindestad, B. (1998). Customer loyalty and complex services: The impact of corporate image on quality, customer satisfaction and loyalty for customers with varying degrees of service expertise. International Journal of Service Industry Management, 9(1), 7-23. doi:10.1108/09564239810199923

Ashby, A., Richardson, J. T. E. \& Woodley, A. (2011). National student feedback surveys in distance education : an investigation at the UK Open University. Open Learning: The Journal of Open Distance and ELeaning, 26(1), 5-25. doi:10.1080/02680513.2011.538560

Aslam, H. D., Ali, A., Iqbal, F., Rahim, K., Saeed, S. \& Abbasi, Z. A. (2012). Analysing Factors Affecting Learning Environment of Universities in Pakistan: A Case of Public sector University of Pakistan. Journal of American Science, 8(9), 56-65.

Aydin, S. \& Ozer, G. (2005). The analysis of antecedents of customer loyalty in the Turkish mobile telecommunication market. European Journal of Marketing, 39(7/8), 910-925.

Baloglu, S. (2002). Dimensions of customer loyalty: separating friends from well wishers. The Cornell Hotel and Restaurant Administration, 43(47), 47-59. Retrieved from http://www.sciencedirect.com/science/article/pii/S0010880402800088

Bennett, R. \& Ali-Choudhury, R. (2009). Prospective students' perceptions of university brands: an empirical study. Journal of Marketing for Higher Education, 19(1), 85-107.

Bianchi, C., Drennan, J. \& Proud, B. (2014). Antecedents of consumer brand loyalty in the Australian wine industry. Journal of Wine Research, (ahead-of-print), 1-14.

Çetin, R. (2011). Institutional Image and Programs in Higher Education. Journal of Marketing for Higher Education Planning and Implementing, 15, 37-41. doi:10.1300/J050v13n01. 
Chaudhuri, A. \& Holbrook, M. (2001). The chain of effects from brand trust and brand affect to brand performance: the role of brand loyalty. Journal of Marketing, 65(2), 81-93. Retrieved from http://journals.ama.org/doi/abs/10.1509/jmkg.65.2.81.18255

Chin, W. W. (1998). The partial least squares approach for structural equation modeling. G.A.Marcoulides (Ed.), Modern Methods for Business Research, (July), 295-336.

Chin, W. W., Marcolin, B. L. \& Newsted, P. R. (2003). A partial least squares latent variable modeling approach for measuring interaction effects: Results from a Monte Carlo simulation study and an electronic-mail emotion/adoption study. Information Systems Research, 14(2), 189-217.

Chun, R. (2005). Corporate reputation: Meaning and measurement. International Journal of Management Reviews, 7(2), 91-109.

Clemes, M. D., Cohen, D. A. \& Wang, Y. (2013). Understanding Chinese university students experiences: an empirical analysis. Asia Pacific Journal of Marketing and Logistics, 25(3), 391-427. doi:10.1108/APJML-07-2012-0068

Cretu, A. E. \& Brodie, R. J. (2007). The influence of brand image and company reputation where manufacturers market to small firms: A customer value perspective. Industrial Marketing Management, 36(2), 230-240.

Fernandes, C., Ross, K. \& Meraj, M. (2013). Understanding student satisfaction and loyalty in the UAE HE sector. International Journal of Education Management, 27(6), 613-630.

Fornell, C. \& Larcker, D. (1981). Evaluating structural equation models with unobservable variables and measurement error. Journal of Marketing Research, 18(1), 39-50.

Gounaris, S. \& Stathakopoulos, V. (2004). Antecedents and consequences of brand loyalty: an empirical study. The Journal of Brand Management, 11(4), 283-306.

Hair, J. F., Sarstedt, M., Ringle, C. M. \& Mena, J. A. (2012). An assessment of the use of partial least squares structural equation modeling in marketing research. Journal of the Academy of Marketing Science, 40, 414-433. doi:10.1007/s11747-011-0261-6

Hair Joseph F., Black, C. W., Babin, B. J. \& Anderson, E. R. (2010). Mutivariate Data Analysis. Upper Saddle River: Pearson Prentice Hall.

Helgesen, Ø. \& Nesset, E. (2007a). Images, Satisfaction and Antecedents: Drivers of Student Loyalty? A Case Study of a Norwegian University College. Corporate Reputation Review, 10(1), 38-59. doi:10.1057/palgrave.crr.1550037

Helgesen, Ø. \& Nesset, E. (2007b). What accounts for students' loyalty? Some field study evidence. International Journal of Educational Management, 21(2), 126-143. doi:10.1108/09513540710729926

Hennig-Thurau, T., Langer, M. F. \& Hansen, U. (2001). Modeling and Managing Student Loyalty An Approach Based on the Concept of Relationship Quality. Journal of Service Research, 3(4), 331-344.

Hosseini, M. H. \& Nahad, R. F. (2012). Investigating antecedents and consequences of open University Brand Image. International Journal of Academic Research, 4(4), 68-77.

Hoyt, J. E. \& Brown, A. B. (2003). Identifying College Choice Factors to Successfully Market Your Institution. College and University, 78(4), 3-10.

Jacoby, J. \& Kyner, D. (1973). Brand loyalty vs. repeat purchasing behavior. Journal of Marketing Research, 10(1), 1-9. Retrieved from http://www.jstor.org/stable/3149402

Jin, N. P., Lee, S. \& Lee, H. (2013, September 30). The Effect of Experience Quality on Perceived Value, Satisfaction, Image and Behavioral Intention of Water Park Patrons: New versus Repeat Visitors. International Journal of Tourism Research. Wiley Online Library. doi:10.1002/jtr.1968

Kandampully, J., Juwaheer, T. D. \& Hu, H. H. (2011). The Influence of a Hotel Firm's Quality of Service and Image and its Effect on Tourism Customer Loyalty. International Journal of Hospitality \& Tourism Administration, 12(1), 21-42. doi:10.1080/15256480.2011.540976

Khairani, A. Z. \& Razak, N. A. (2013). Assessing Factors Influencing Students Choice of Malaysian Public University: A Rasch Model Analysis. International Journal of Applied Psychology, 3(1), 19-24.

Khan, M. M., Ahmed, I. \& Nawaz, M. M. (2011). Student 's Perspective of Service Quality in Higher Learning Institutions ; An evidence Based Approach. International Journal of Business and Social Science, 2(11), 159-164.

Kotler, P. \& Fox, K. F. A. (1995). Strategic marketing for educational institutions. Prentice-Hall Englewood Cliffs, NJ. 
Lemmink, J., Schuijf, A. \& Streukens, S. (2003). The role of corporate image and company employment image in explaining application intentions. Journal of Economic Psychology, 24(1), 1-15.

Liat, C. B., Mansori, S. \& Huei, C. T. (2014). The Associations Between Service Quality, Corporate Image, Customer Satisfaction, and Loyalty: Evidence From the Malaysian Hotel Industry. Journal of Hospitality Marketing \& Management, 23(3), 314-326. doi:10.1080/19368623.2013.796867

Lin, Z. \& He, X. (2014). The images of foreign versus domestic retailer brands in China : A model of corporate brand image and store image. Journal of Brand Management, 2, 1-18. doi:10.1057/bm.2014.26

Lother, A. K. (1997). Service Quality. Journal of International Hospitality, Leisure and Tourism Management, 1(4), 63-77. doi:10.1016/S0031-9406(05)65720-3

Louis, D. \& Lombart, C. (2010). Impact of brand personality on three major relational consequences (trust, attachment, and commitment to the brand). Journal of Product \& Brand Management, 19(2), 114-130.

Lymar, V. \& Mohajerani, K. (2013). Brand Image of Umeå University: A Quantitative Study of the Effects on Students' Attachment and Commitment. Retrieved from http://www.diva-portal.org.scihub.org/smash/get/diva2:633927/FULLTEXT01.pdf

Mercedes, M. N., Pedraja-Iglesias, M. \& Rivera-Torres, M. P. (2005). Measuring customer satisfaction in summer courses. Quality Assurance in Education, 13(1), 53-65.

Milfelner, B., Snoj, B. \& Pisnik Korda, A. (2011). Measurement of Perceived Quality, Perceived Value, Image, and Satisfaction Interrelations of Hotel Services: Comparison of Tourists From Slovenia and Italy. Drustvena Istrazivanja, 20, 602-624. doi:10.5559/di.20.3.01

Mupemhi, S. (2013). Factors influencing choice of a university by students in Zimbabwe. Academic Journals, 7(36), 3723-3729. doi:10.5897/AJBM2013.7077

Nadiri, H., Kandampully, J. \& Hussain, K. (2009). Students' perceptions of service quality in higher education. Total Quality Management \& Business Excellence, 20(5), 523-535. doi:10.1080/14783360902863713

Nguyen, N. \& LeBlanc, G. (2001). Image and reputation of higher education institutions in student retention decisions. International Journal of Educational Management, 15(6), 303-311.

Nunnally, J. C. \& Bernstein, I. H. (1978). Psychometric Theory.pdf (Second Edi.). New york: McGraw-Hill INC.

Obermeit, K. (2012). Students ' choice of universities in Germany : structure, factors and information sources used. Journal of Marketing for Higher Education, 22(2), 206-230.

Oliver, R. L. (1999). Whence consumer loyalty? The Journal of Marketing, 63(Special Issue), 33-44.

Olmedo-Cifuentes, I., Martinez-Leon, I. M. \& Davies, G. (2014). Managing internal stakeholders' views of corporate reputation. Service Business, 8(1), 83-111.

Perin, M. G., Sampaio, C. H., Simoes, C. \& de Polvora, R. P. (2012). Modeling antecedents of student loyalty in higher education. Journal of Marketing for Higher Education, 22(1), 101-116.

Richardson, J. T. E., Slater, J. B. \& Wilson, J. (2007a). The National Student Survey : development, findings and implications. Studies in Higher Education, 32(5), 557-580. doi:10.1080/03075070701573757

Richardson, J. T. E., Slater, J. B. \& Wilson, J. (2007b). The national student survey: development, findings and implications. Studies in Higher Education, 32(5), 557-580.

Ringle, C. M., Wende, S. \& Will, S. (2005). SmartPLS 2.0 (M3) Beta, Hamburg. http://www.smartpls.de

Rubeena Cetin. (2004). Planning and implementing institutional image and promoting academic programs in higher education. Journal of Marketing for Higher Education, 13(1-2), 57-75.

Sean Hyun, S. \& Kim, W. (2011). Dimensions of Brand Equity in the Chain Restaurant Industry. Cornell Hospitality Quarterly, 52, 429-437. doi:10.1177/1938965510397533

Sirdeshmukh, D., Singh, J. \& Sabol, B. (2002). Consumer trust, value, and loyalty in relational exchanges. Journal of Marketing, 66, 15-37. Retrieved from http://journals.ama.org.scihub.org/doi/abs/10.1509/jmkg.66.1.15.18449

So, J. T., Parsons, A. G. \& Yap, S. F. (2013). Corporate branding, emotional attachment and brand loyalty: the case of luxury fashion branding. Journal of Fashion Marketing and Management, 17(4), 403-423.

Sui, J. J. (2003). The Role of Emotional Commitment in Relationship Marketing: An Empirical Investigation of a Loyalty Model for Casinos. Journal of Hospitality \& Tourism Research, 27(4), 470-489. doi:10.1177/10963480030274006

Sultan, P. \& Wong, H. Y. (2010). Service quality in higher education- a review and research agenda. International Journal of Quality and Service Sciences, 2(2), 259-272.

Tas, A. \& Ergin, E. A. (2012). Key Factors for Student Recruitment: The Issue of University Branding. International Business Research, 5(10), p146. 
Tran, M. A., Nguyen, B., Melewar, T. C. \& Bodoh, J. (2015). Exploring the corporate image formation process. Qualitative Market Research: An International Journal, 18(1), 86-114. doi:10.1108/QMR-05-20140046

Tran, M. A., Nguyen, B., Melewar, T. C. \& Bodoh, J. (2015). Exploring the corporate image formation process. Qualitative Market Research: An International Journal, 18(1), 86-114.

Urbach, N. \& Ahlemann, F. (2010). Structural equation modeling in information systems research using partial least squares. Journal of Information Technology Theory and Application, 11(2), 5-40. Retrieved from http://iris.ebs.edu.scihub.org/accessdb/WWW/iris_pub_web.nsf/wwwPublAuthorSingleEng/A58520D5E3C484DCC1257 C50007F8697/\$file/Urbach et al. 2010 Structural Equation Modeling in IS Research Using PLS.pdf

Vander Schee, B. (2011). Students as Consumers: Programming for Brand Loyalty. Services Marketing Quarterly, 32(1), 32-43. doi:10.1080/15332969.2011.534331

Vander Schee, B. A. (2010). Students as Consumers: Programming for Brand Loyalty. Services Marketing Quarterly, 32(1), 32-43.

Watkins, B. A. \& Gonzenbach, W. J. (2013). Assessing university brand personality through logos: an analysis of the use of academics and athletics in university branding. Journal of Marketing for Higher Education, 23(1), 15-33.

Williams Jr, R., Osei, C. \& Omar, M. (2012). Higher Education Institution branding as a component of country branding in Ghana: Renaming Kwame Nkrumah University of Science and Technology. Journal of Marketing for Higher Education, 22(1), 71-81.

Wu, H. C. (2013). An Empirical Study of the Effects of Service Quality, Perceived Value, Corporate Image, and Customer Satisfaction on Behavioral Intentions in the Taiwan Quick Service Restaurant Industry. Journal of Quality Assurance in Hospitality \& Tourism, 14, 364-390. doi:10.1080/1528008X.2013.802581

Zeithaml, V. A., Berry, L. \& Parasuraman, A. (1988). Communication and control Processes in the Delivery of Service Conceptual Model of Service Quality. Journal of Marketing, 52(2), 35-48.

Zeithaml, V. A., Berry, L. L. \& Parasuraman, A. (1996). The behavioral consequences of service quality. Journal of Marketing, 60, 31-46. doi:10.2307/1251929

Zeithmal, V., Parasuraman, A. \& Berry, L. (1990). Delivering quality service: Balancing customer perceptions and expectations. The free Press. New York: A decision of Simon \& Schuster Inc. 